\title{
Impacts of "Storis" on the Thermohaline Stratification off West Greenland
}

\author{
Manfred Stein \\ Johann Heinrich von Thünen-Institut \\ Institut für Seefischerei, Palmaille 9, D-22767 Hamburg, Federal Republic of Germany \\ E-mail: manfred.stein@,vti.bund.de
}

Stein, M. 2010. Impacts of "Storis" on the Thermohaline Stratification off West Greenland. J. Northw. Atl. Fish. Sci., 43: 1-12. doi:10.2960/J.v43.m655

\begin{abstract}
This paper examines the variability in the hydrographic conditions in the waters off West Greenland with a focus on the influence of the Polar Water off East Greenland and its associated sea ice or "Storis". During the mid-1970s, mid-1980s and early-1990s, maxima of Polar Water were observed in the upper water layers off Fyllas Bank, West Greenland. At a station located on the offshore bank slope in about $900 \mathrm{~m}$ of water, the upper $75 \mathrm{~m}$ of the water column are primarily influenced by the Polar Water and the "Storis". There, monthly mean temperatures are maximum and salinities a minimum during August-September. In years of larger than usual amounts of "Storis", cold diluted surface waters appear along the west coast of Greenland. Observations of sea surface temperature anomalies off Fyllas Bank during July indicate strong warming from 1989 to 2008, going from what appears to be the coldest year to close to the warmest. Warm anomalies were actually re-established in 1996. Warmer-than-normal sub-surface conditions peaked in 2003, a year with no "Storis". From 2002 onwards, a phenomenon is observed which seems to indicate a new structure in the distribution of SST anomalies: a band of colder-than-normal waters on the shelves off East and West Greenland. It is assumed that the continuous warming has led to massive sea ice melt off East Greenland, and the ice drifts with the East Greenland Current along the shelves off East and West Greenland, strongly influencing the temperature and salinity characteristics of the surface waters.
\end{abstract}

Keywords: current, thermohaline, Storis, stratification, West Greenland

\section{Introduction}

Greenland waters are influenced by two ocean currents - the cold East Greenland Current and the warm Irminger Current (Fig. 1). The East Greenland Current originates from the Greenland Sea, and flows southward along the East Greenland shelf carrying with it polar waters. This Current rounds Cape Farewell, the southern tip of Greenland, and flows northward along the west coast of Greenland. Parallel to the East Greenland Current, the Irminger Current (a western branch of the Gulf Stream system) flows southward off East Greenland and then turns northwards after rounding Cape Farewell. As this latter current flows northward along the slope, its warm, saline waters mix with the colder, fresher sub-arctic water masses in the Labrador Sea and on the Greenland Shelf, and upon reaching Davis Strait with waters coming south from Baffin Bay. Over the West Greenland Shelf and banks, the near bottom waters become warmer when moving from south to north, due to an increasing influence of the warm Irminger Water. With the warming climate during the 1920 s, the influence of this warm water increased at the expense of the colder water originating from East Greenland (Stein, 2007). Cold and low saline events were observed during the early-1970s, 1980s and 1990s. During the second half of the 1990s, thermal conditions in West Greenland waters were in the range of the warm 1960s (Stein, 2004). Observations of the sea surface temperature anomalies in the North Atlantic Subpolar Gyre indicate cold conditions in the 1980s and warming from the mid-1990s onwards, with maximum temperatures observed during October 2003. This is consistent with air temperatures at Nuuk, Greenland, which document that 2003 was the warmest year since 1950 (Stein, 2007).

There are two main types of sea ice which dominate in West Greenland waters (Buch, 2000; Buch et al., 2004):

"Storis" that is of polar origin and advected to Southwest Greenland by the East Greenland Current, and "Westice" that is formed in Baffin Bay and Davis Strait. 


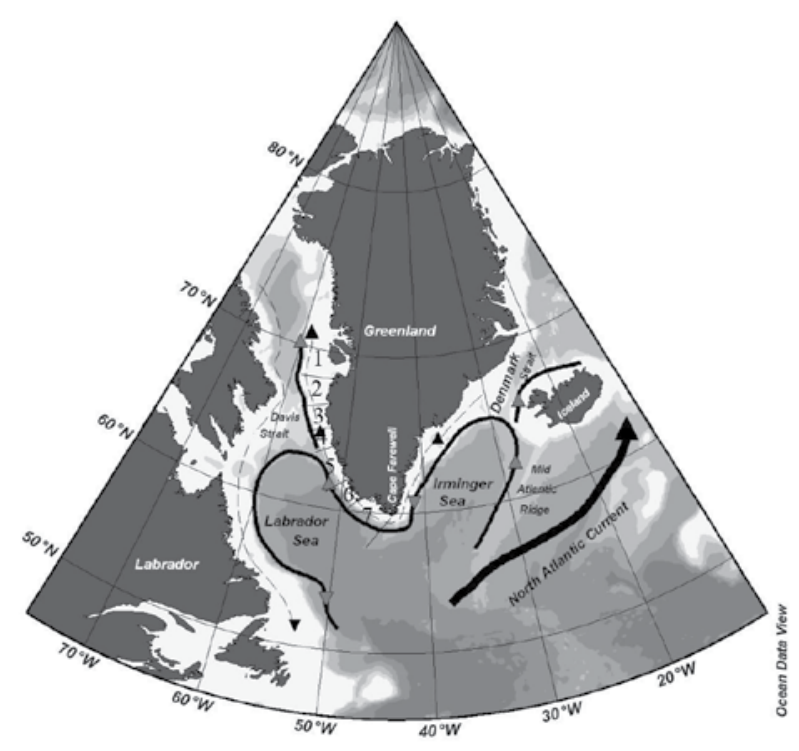

Fig. 1. Schematic of the subpolar gyre (white area: 0-500 m depth). Bold: warm currents; dashed: cold currents. Approximate locations of 1. Egedesminde; 2. Holsteinsberg; 3. Lille Hellefiskebanke; 4. Fylla Bank; 5 Frederikshaab; 6. Cape Desolation; and 7. Cape Farewell Standard Oceanographic Sections (Stein, MS 1988). Figure modified from Stein, 2005.

The magnitude of "Storis" off Southwest Greenland depends on the sea ice conditions in the Greenland Sea, and on wind conditions off East and West Greenland. The "Westice" starts to form in Baffin Bay, and spreads along the East Canadian coast and the northwest Greenland coast. Due to the inflow of the warm Irminger Current, the waters off southwest Greenland are normally not affected by "Westice". Information on sea ice conditions off Greenland from the early-1990s onwards is reported on an annual basis to NAFO (e.g. Stein, 1995a, b; 2008). During midsummer, the time of maximum "Storis" melt, cold water with temperatures below $2{ }^{\circ} \mathrm{C}$ advances farthest north along West Greenland, and dispels Atlantic cod (Gadus morhua) from the shallow parts of the banks. This is the start of the "slack-period", a period of depressed catches of cod off West Greenland during mid-July to mid-August (Meyer, 1953).

Following a description of the data used in this study, the seasonal and interannual variability of the hydrographic conditions off West Greenland are discussed based upon time series of sub-surface $(0-500 \mathrm{~m})$ temperature and salinity from 1946 to 1988 . Then an analysis of the influence of "Storis" conditions on the water mass structure along NAFO Standard Section Frederikshaab (Stein, MS 1988) is presented. Satellite-derived July sea surface temperature anomalies (SSTAs) during 19892008 for the region between Greenland and Labrador are considered thereafter. The final section presents a discussion of the results including the potential impact of "Storis" on the stratification of near-surface waters.

\section{Data and Methods}

Most of the oceanographic data in this study were taken from the World Ocean Database 2005 (WOD, 2005) and consist of both bottle and CTD data. They were updated with data collected by Denmark and Germany. To reveal changes in the thermohaline conditions off West Greenland, the variability in the 0-500 $\mathrm{m}$ water layer at Station 4 along the Fyllas Bank section for the period 1946-1988 are used. Station 4 is located over the continental shelf and was chosen for two reasons: (1) this international standard station (Stein, MS 1988) off West Greenland provides maximum temporal coverage, and (2) the subsurface oceanic variability measured at this slope station is a good proxy for subsurface ocean variability off West Greenland (Stein, 2004). To examine seasonal changes, mean values of temperature and salinity were calculated for different layers in the upper $500 \mathrm{~m}$ of Station 4 Fyllas Bank (0-75 m, 100-200 m, 250-300 m, and 400-500 m). Estimates of standard errors and their statistical significance are given for the 0-500 m layer. Thermohaline conditions for the upper $150 \mathrm{~m}$ at Station 4 Fyllas Bank during recent years are provided using a composite of June-July CTD data during 1989-2006. As a proxy for vertical stratification, $\mathrm{d} \sigma_{\theta} / \mathrm{d} z$ was calculated (where $\sigma_{\theta}$ is the density anomaly at the potential temperature $\theta$ and $z$ is the vertical axis) and plotted over the same period from the June-July CTD data. Oceanographic sections were constructed by keeping the settings of interpolation metrics for temperature and salinity scales constant.

A water mass analysis was carried out for Polar and Irminger waters. The definition of Polar Water at the fishing banks off West Greenland was taken from Buch (2000) as $\theta<1^{\circ} \mathrm{C}$ (but can rise to $3-5^{\circ} \mathrm{C}$ in the surface layer during summer due to solar heating) and $\mathrm{S}<33.75$. The definition for Irminger Water was taken as $4^{\circ} \mathrm{C}<\theta<6^{\circ} \mathrm{C}, 34.95<\mathrm{S}<35.1$, following Clarke (1984).

Ice charts were obtained from: the National Ice Center (NIC, 2009). July sea surface temperature anomalies (SSTAs) for the region $50^{\circ} \mathrm{N}-70^{\circ} \mathrm{N}, 60^{\circ} \mathrm{W}-30^{\circ} \mathrm{W}$ between Greenland and Labrador were taken from the IGOSS database (IGOSS, 2009). The climatology is referenced to $1971-2000$. 
Data analysis and presentation was undertaken using Ocean Data View (Version 3.4.2, 2008; Schlitzer, 2008).

\section{Results}

The variability in the hydrography off West Greenland is first explored using data from Station 4 Fyllas Bank. Seasonal variation of temperature and salinity in the 0-500 $\mathrm{m}$ layer at this station, based on bottle data, is given in Fig. 2a. The lowest temperatures occur during April and highest temperatures during November whereas salinity is highest during March and lowest during August. The 95\% confidence intervals for monthly temperature and salinity data reveal, however, that in most cases there is no significant difference between neighbouring monthly values. Seasonal temperature and salinity variations in four different layers over the upper$500 \mathrm{~m}$ are given in Fig. 2b. They show that in the nearsurface layer $(0-75 \mathrm{~m})$ the warmest conditions are found during August-September, accompanied by the lowest salinities. Cold temperatures and high salinities are found during January-May. The seasonal changes of the deeper layers (100-200 m, 250-300 m and 400-500 m)
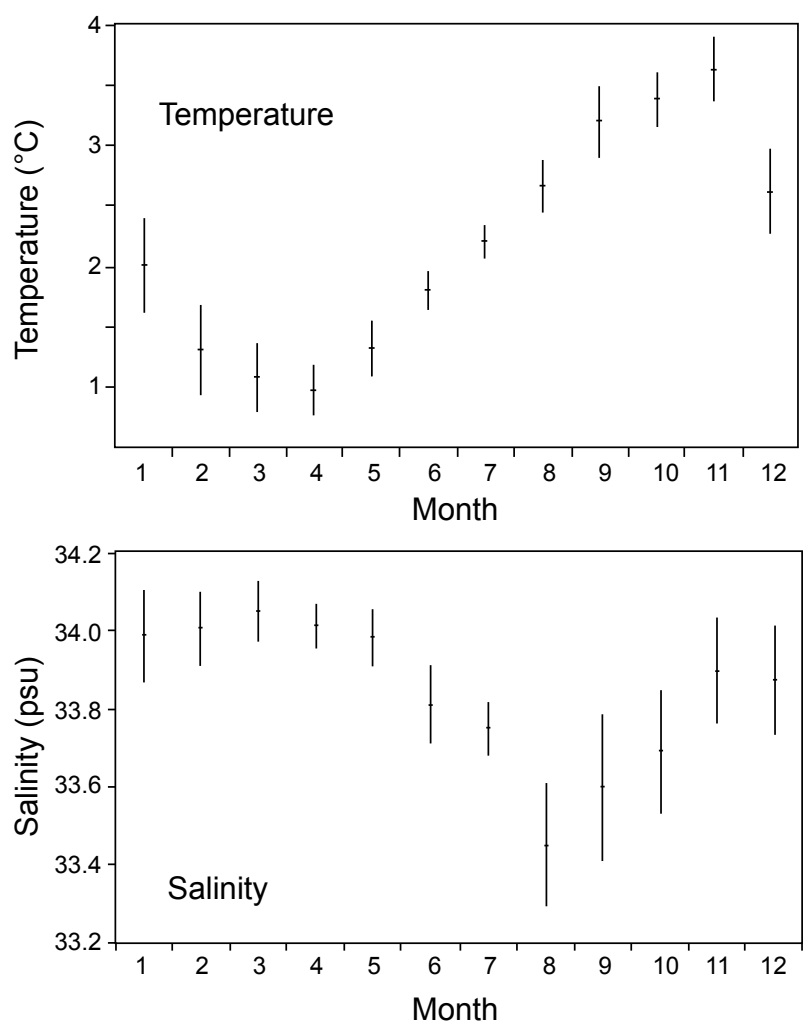

Fig. 2a. The seasonal variation of thermohaline conditions over the 0-500 $\mathrm{m}$ depth range at Station 4, Fyllas Bank, from 1946-1988. Monthly means and 95\% confidence intervals shown. look similar, but the amplitudes of seasonal $\theta$, S-changes decrease with deepening layers. Warmest conditions are encountered during October-November, with highest salinities during the same time. Minimum temperatures and salinities of the deeper layers are found during JuneAugust.

The interannual variability in the July observations at Station 4 Fyllas Bank, indicates a deepening of the 33.75 isohaline (the upper boundary of the Polar Water) from the late-1940s to the beginning of the 1970s (Fig. 3). During the following decade, however, the depth of the Polar Water layer decreased. This was followed by another deepening of this cold water domain during the 1980s, resulting in an approximate $150 \mathrm{~m}$ layer of Polar Water. There are also several occasions where the Polar Water is heated by solar radiation with near-surface temperatures increasing to $3-5^{\circ} \mathrm{C}$ (e.g. 1946, 1961, 1977-1980). The temperature shows significant differences between the 1950s-1960s and the 1970s-1980s. Whereas during the first period Polar Water was present only occasionally at
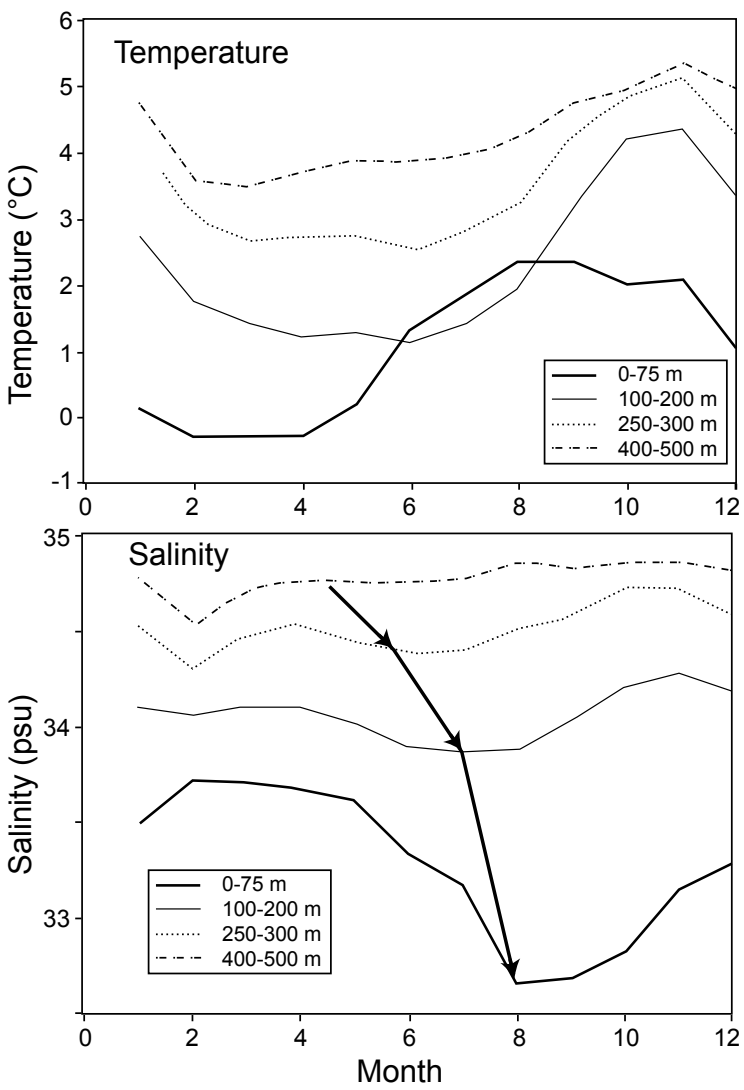

Fig. $2 b$. The seasonal variation of thermohaline conditions in the 0-75 m, 100-200 m, 250-300 m, and 400-500 m depth ranges, at Station 4, Fyllas Bank, from 19461988. Monthly means shown, with the arrows indicating salinity minima. 

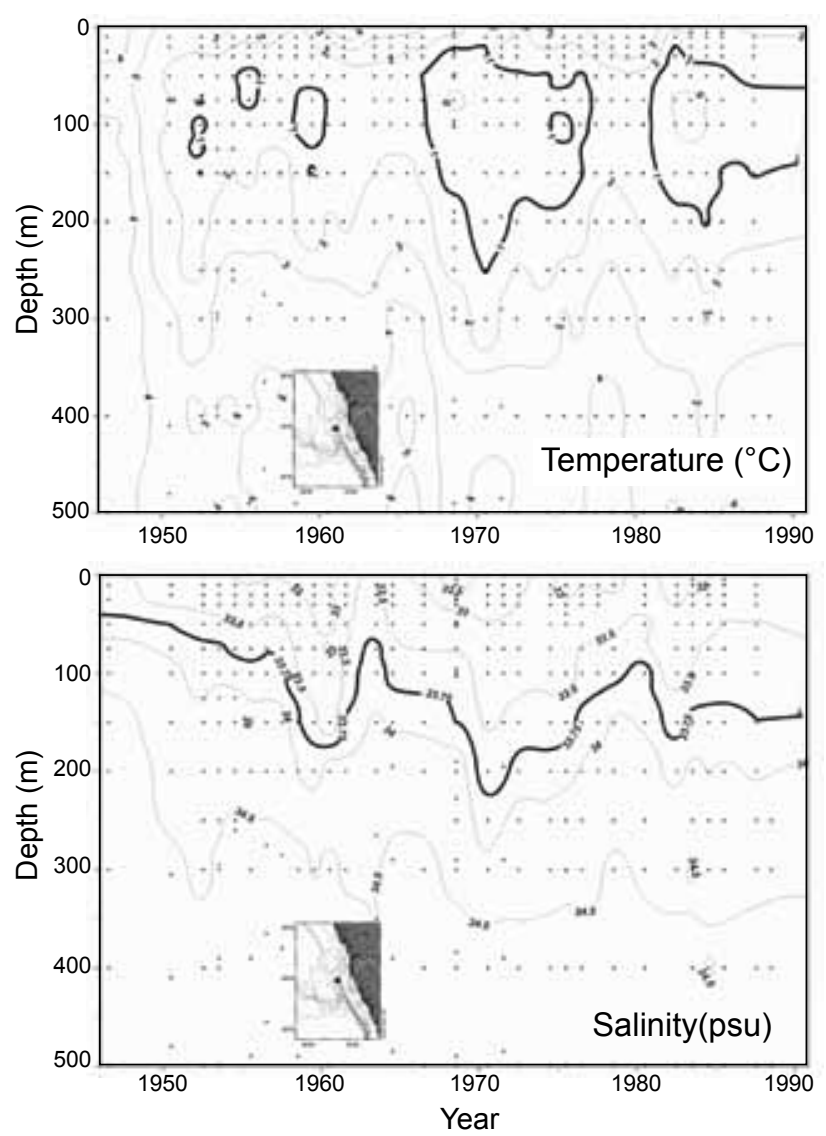

Fig. 3. Thermohaline conditions $(0-500 \mathrm{~m})$ at Station 4 Fyllas Bank (inset) during July 1946-1988. The isolines of upper bounds of the water mass characteristics for Polar Water $\left(<1^{\circ} \mathrm{C},<33.75 \mathrm{psu}\right)$ are given in bold. The plots are derived from bottle data only.

Station 4 Fyllas Bank (during July of 1952, 1955, and 1959; Fig. 3), during the 1970s and 1980s considerable amounts of subsurface Polar Water were observed with temperatures $<1{ }^{\circ} \mathrm{C}$ water. In the early-1970s, this water mass covered the range from $50 \mathrm{~m}$ to $200 \mathrm{~m}$ depth. During 1982-1987 (there were no $\theta, \mathrm{S}$ data collected in the upper-200 m during 1988), Polar Water dominated the subsurface waters down to $150 \mathrm{~m}$.

The June-July thermohaline conditions off Fyllas Bank, based on CTD data (Fig. 4), clearly indicate the enormous cooling during the early-1990s. From 1996 onwards, there is no Polar Water (except for small patches in the subsurface layers). Patches of warm, diluted surface waters and their stability is documented in the lower panel of Fig. 4.

Thermohaline conditions off West Greenland during an extreme midsummer "Storis" situation observed during July 1999 reveals a cold, low salinity water mass

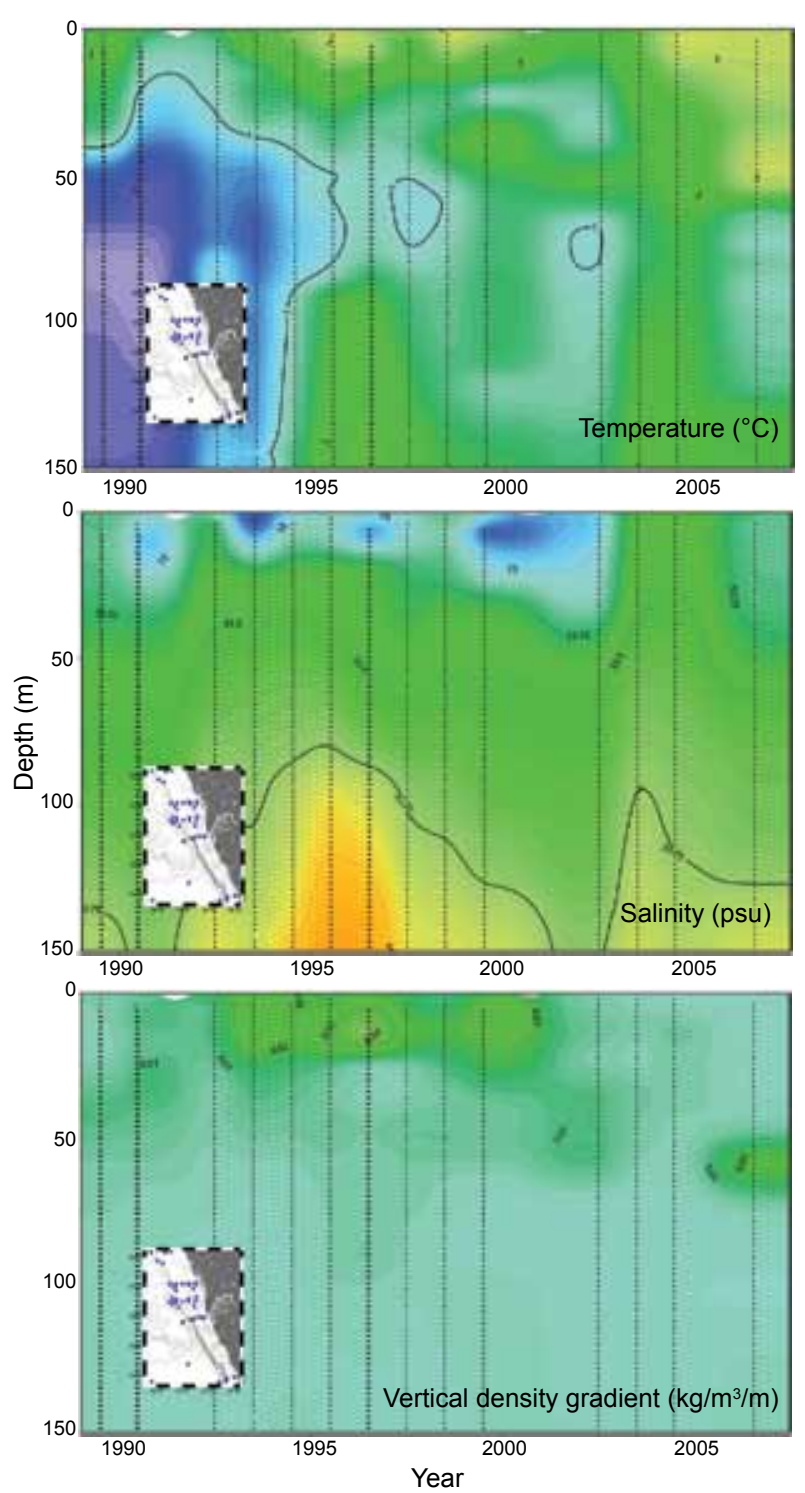

Fig. 4. Thermohaline conditions $(0-150 \mathrm{~m})$ and stability of stratification at Station 4 Fyllas Bank (inset) during June-July 1989-2006. The isopleths of the upper bounds of the characteristics for Polar Water $\left(<1^{\circ} \mathrm{C}\right.$, $<33.75 \mathrm{psu}$ ) are shown in bold.

covering Frederikshaab Bank (Fig. 5). The Polar Water reaches far west off the slope, and $<33.75$ salinities are seen at the surface of the entire section. Note though that this water was not observed at Station 4 on Fyllas Bank (see above). Density gradients in the surface layer over Frederikshaab Bank are $0.01<\mathrm{d \sigma}_{\theta} / \mathrm{d} z<0.02\left(\mathrm{~kg} / \mathrm{m}^{3} / \mathrm{m}\right)$ in the oceanic domain of the section, whereas on the shelf the stratification is considerable higher, $0.04<\mathrm{d \sigma}_{\theta} /$ $\mathrm{d} z<0.07\left(\mathrm{~kg} / \mathrm{m}^{3} / \mathrm{m}\right)$. Fig. 6 gives the thermohaline situation off West Greenland during ice free conditions in July 2003. In the slope region of the section, the influence of the Polar Water, as given by $\mathrm{S}<33.75$ (middle 


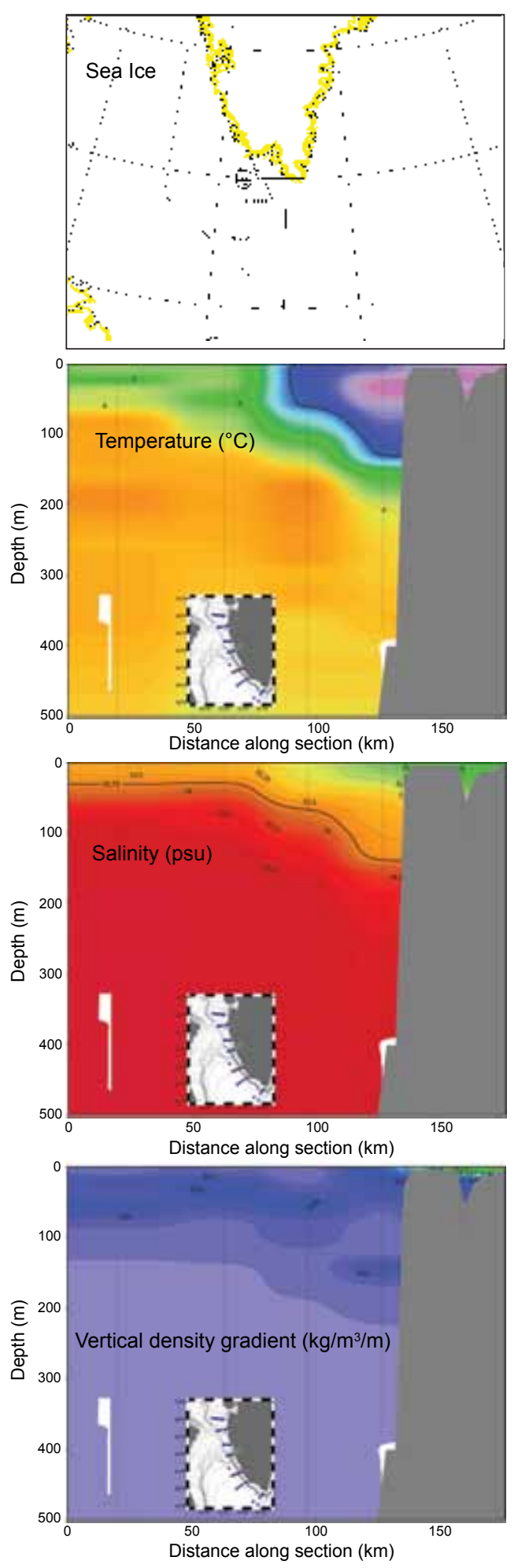

Fig. 5. Sea ice distribution off West Greenland on 5-9 July 1999 and thermohaline conditions at Frederikshab Section (inset) on 4 July 1999. The upper bound of the Polar Water (33.75 psu) is marked by a bold line. Sampling locations along the section are show by the fine vertical dashed lines.
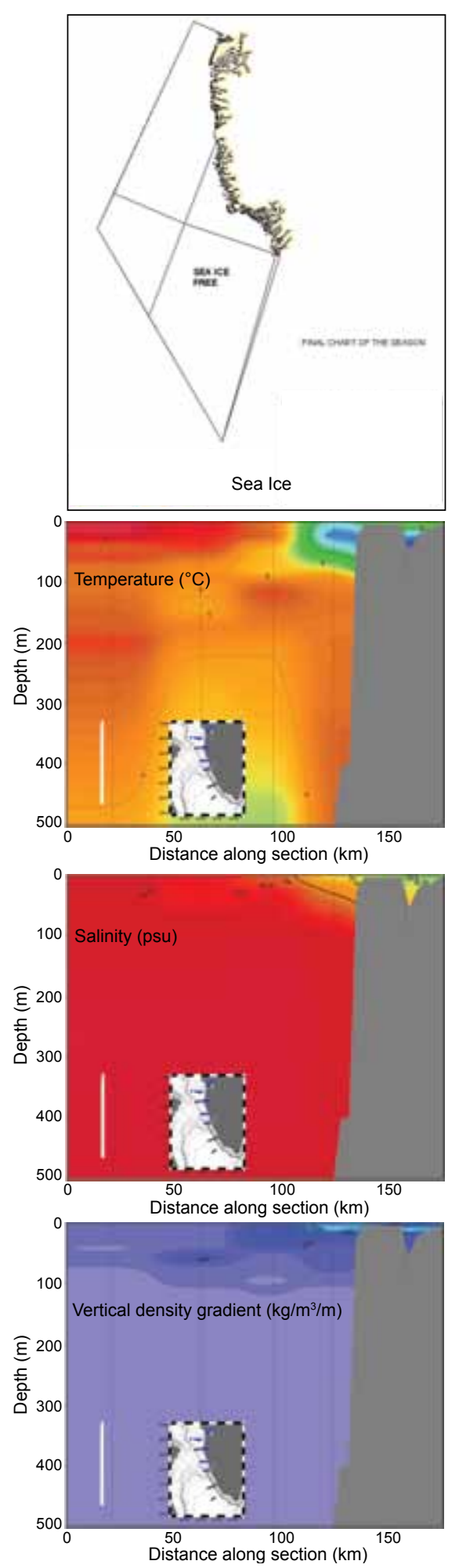

Fig. 6. Sea ice distribution off West Greenland on 7-11 July 2003 and thermohaline conditions at Frederikshaab Section (see inset) on 1-2 July 2003. The upper bound of the Polar Water (33.75 psu) is marked by a bold line. Sampling locations along the section are show by the fine vertical dashed lines. 
panel of Fig. 6), extends down to only $50 \mathrm{~m}$ depth, and spreads about $25 \mathrm{~km}$ to the west off Frederikshaab Bank. Density gradients of the surface layer are $0.01<\mathrm{d \sigma}_{\theta} / \mathrm{d} z$ $<0.04\left(\mathrm{~kg} / \mathrm{m}^{3} / \mathrm{m}\right)$ in the oceanic domain of the section, and similar values are obtained from the on-shelf part of the Frederikshaab Bank Section.
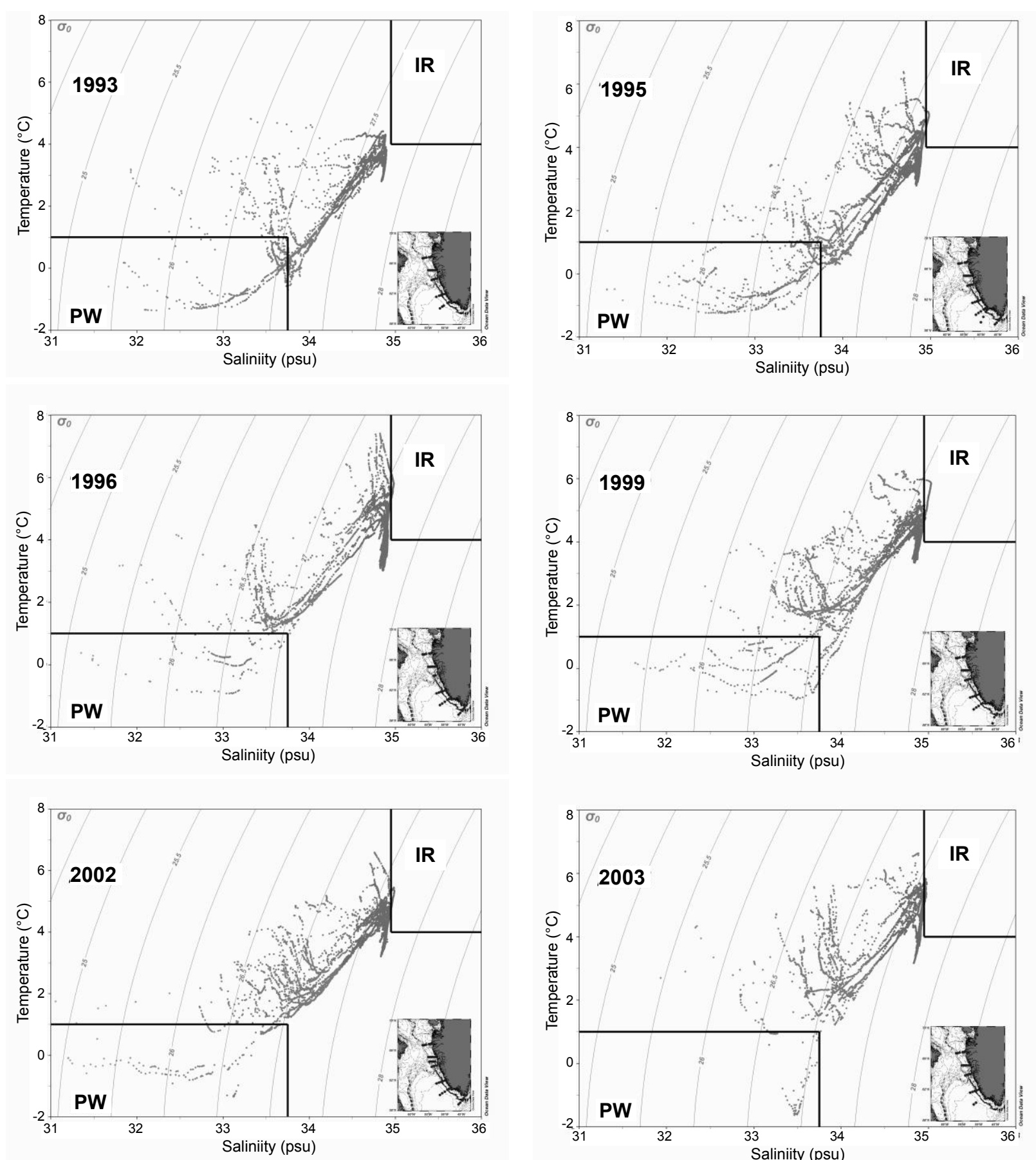

The $\theta, \mathrm{S}$ diagrams of West Greenland oceanographic stations collected during July 1993-2003 by Denmark (Figs. 7 and 8) reveal that during "Storis" situations, Polar Water was observed in all years $(\theta, \mathrm{S}$ points in the lower left box in all panels of Fig. 7). In July 2003

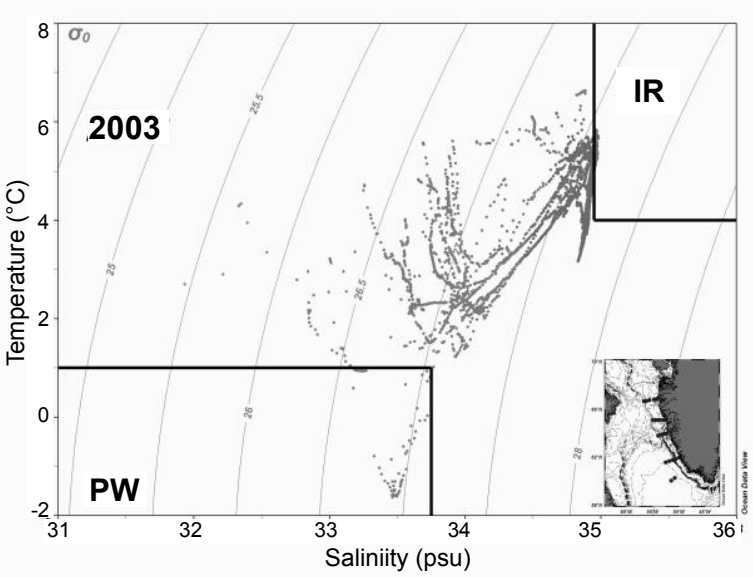

Fig. 7. Temperature-Salinity diagrams, with lines of equal density, from West Greenland oceanographic stations collected during July 1993-2003. Rectangles denote Polar and Irminger water masses. 
there was no "Storis" although $\theta, \mathrm{S}$ characteristics similar to that of Polar Water were observed. These belong to the westernmost station of the Holsteinsborg section, and are from the Baffin Island Current waters. A closer view of the $\theta, \mathrm{S}$ conditions off West Greenland during a "Storis" and a non-"Storis" year is given in Fig. 8. The westernmost station of the Holsteinsborg Section, for 1999 and 2003 in Figs. 5 and 6, is marked by triangles in Fig. 8, and these $\theta, \mathrm{S}$ values are not a consequence of the effects of "Storis". Instead they are, as mentioned above, the characteristics of the Baffin Island Current. In the Polar Water domain for 2003 (lower panel of Fig. 8) there is little Polar Water during the visit to the station on 4 July 2003, one week before the Holsteinsborg Section was occupied. Except for 1993, during all years Irminger
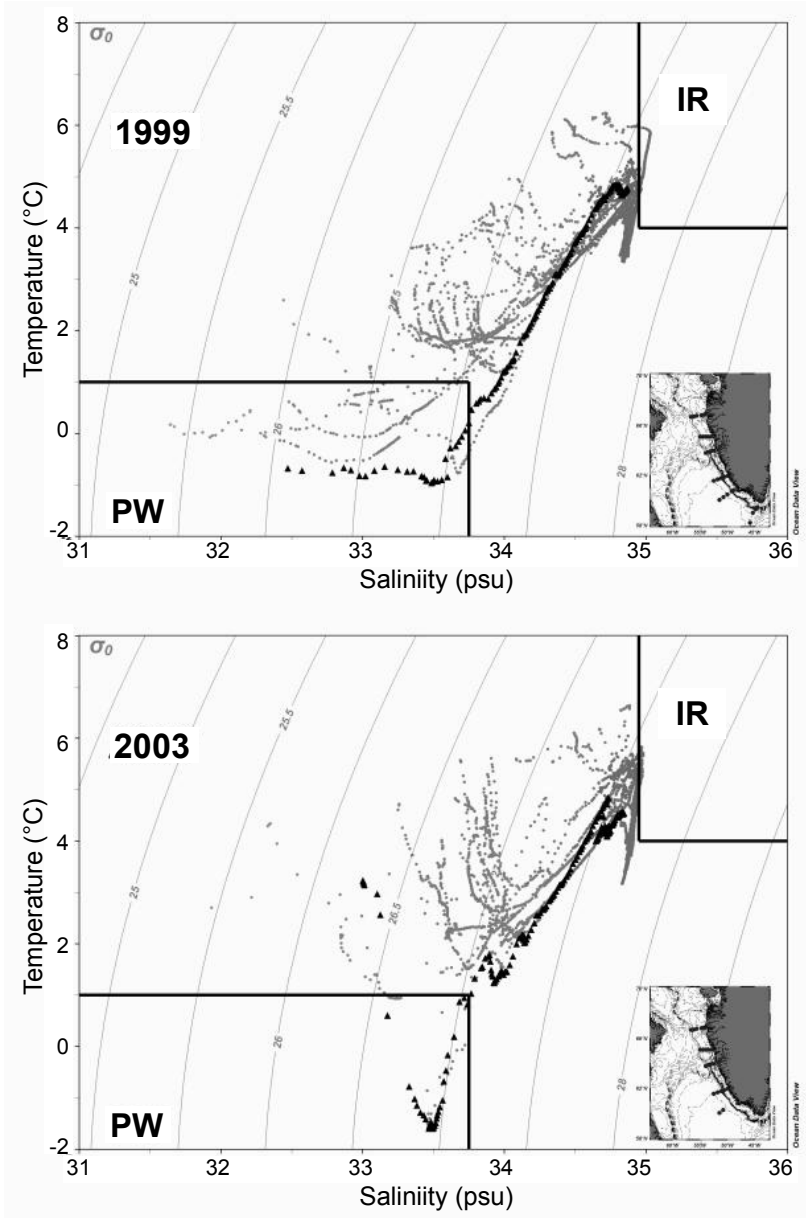

Fig. 8. Temperature-salinity diagrams, with lines of equal density, of West Greenland oceanographic stations, for July 1999-2003. Rectangles denote Polar and Irminger water masses. Triangles are from the westernmost station along the Holsteinsborg Section (see inset).
Water was observed at depth off West Greenland (upper right box in Figs. 7 and 8).

A recent year with "Storis" is shown in Figs. 9 and 10. There was a tongue of sea ice in the Cape Farewell/ Julianehaab Bight region which extended up off Paamiut during 21-25 April 2008. Remnants of "Storis" during the 2008 season were encountered during mid-July before the area became ice free by the end of July.

July sea surface temperature anomaly (SSTA) data for the region between Greenland and Labrador are given in Fig. 11a-c. Colder-than-normal SSTs are seen in July throughout most of 1989-1995, except for 1991

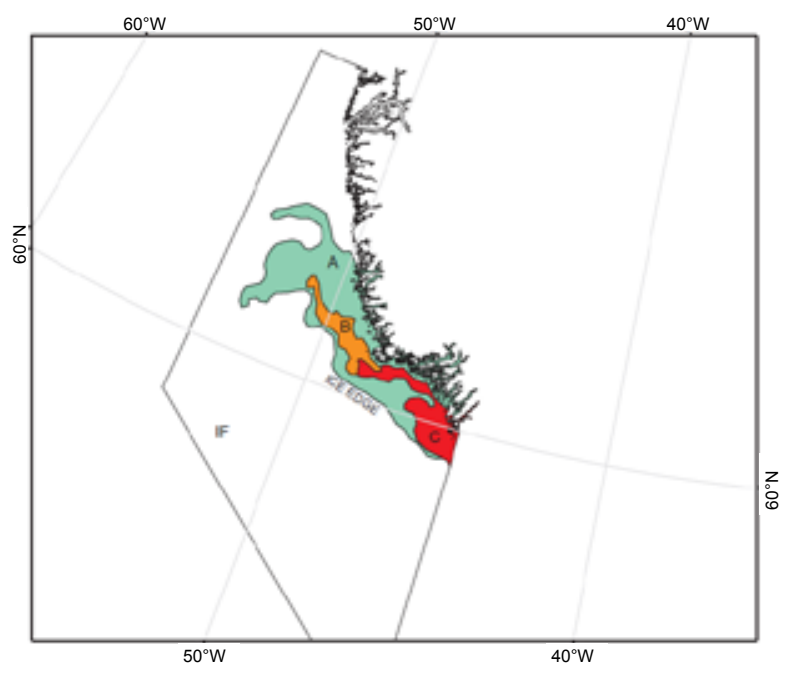

Fig. 9. Sea-ice cover and ice edge during 21-25 April 2008.

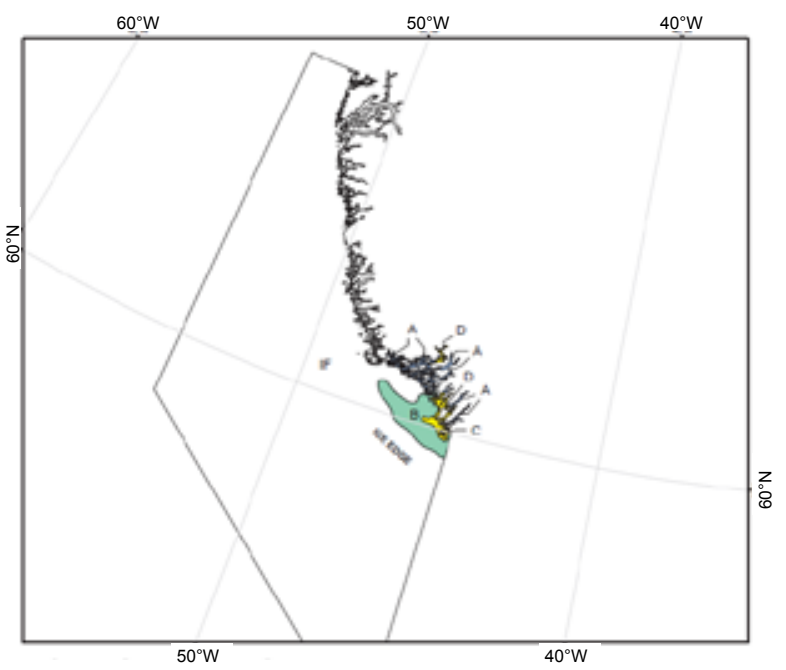

Fig. 10. Sea-ice cover and ice edge during 14-18 July 2008. 

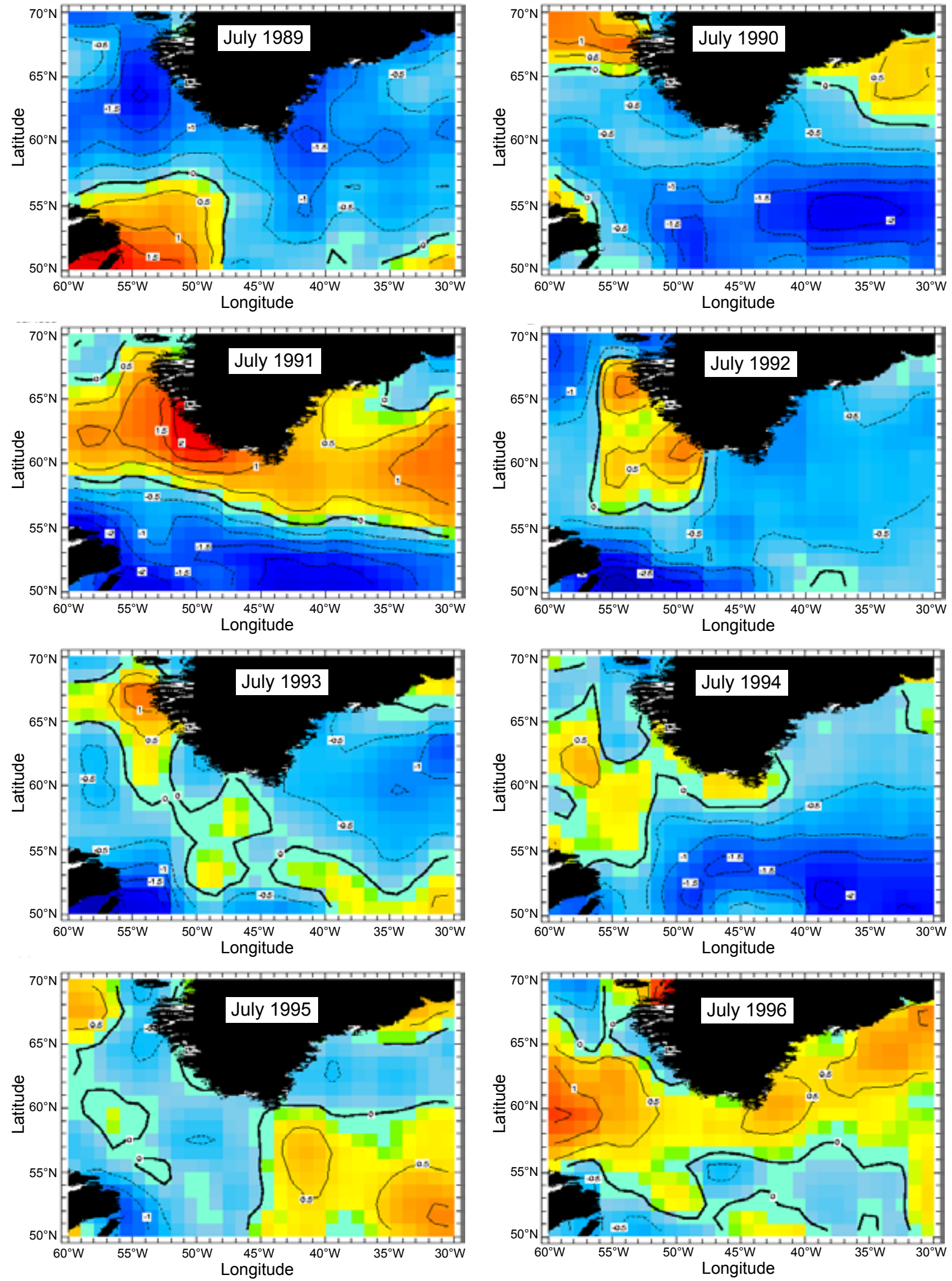

Fig. 11a. Sea surface temperature anomalies $\left({ }^{\circ} \mathrm{C}\right)$ around Greenland for July of 1989-1996 based on the IGOSS database. 
STEIN: Thermohaline Stratification off West Greenland
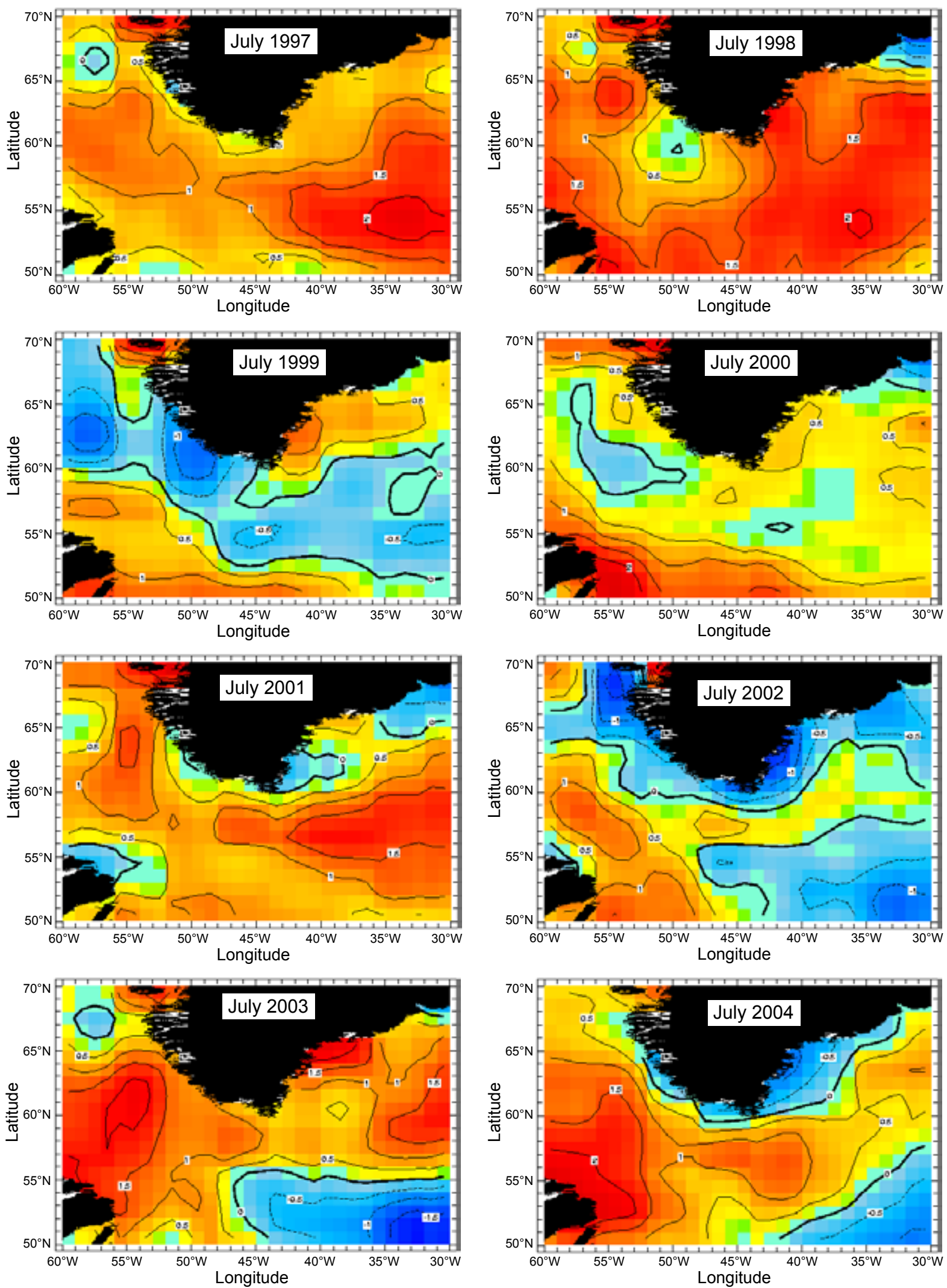

Fig. 11 b. Sea surface temperature anomalies $\left({ }^{\circ} \mathrm{C}\right)$ around Greenland for July of 1997-2004 based on the IGOSS database. 

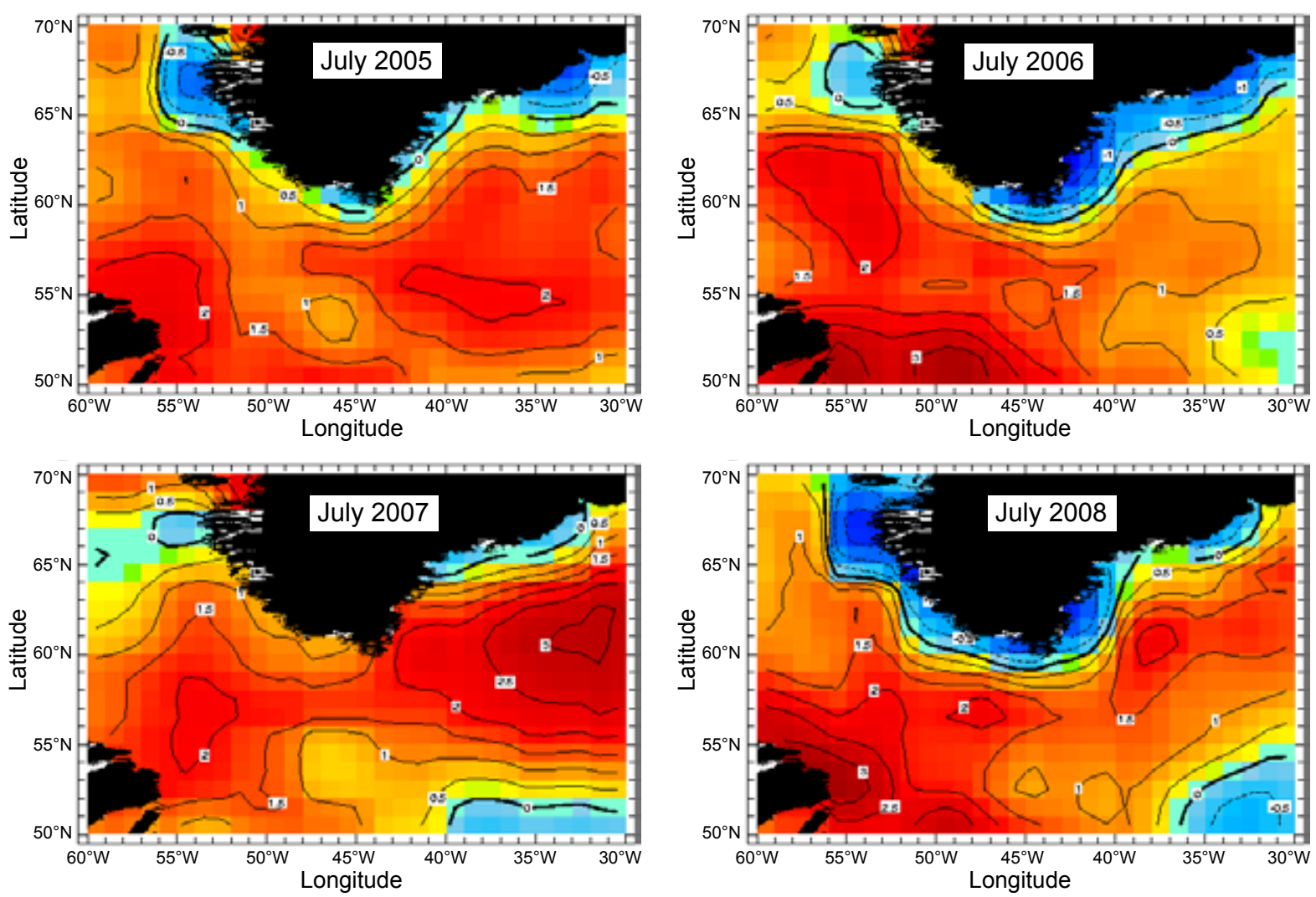

Fig. 11c. Sea surface temperature anomalies $\left({ }^{\circ} \mathrm{C}\right)$ around Greenland for July of 2005-2008 based on the IGOSS database.

and 1992 (Fig. 11a). The onset of warmer-than-normal midsummer SSTs occurs in 1996. From 2002 onwards, a cold anomaly pattern develops over the East and West Greenland shelves along with warm anomalies over the rest of the Labrador Sea gyre and the Irminger Sea. This pattern was most evident in 2005 and 2008 (Fig. 11c). This structure was not only seen during July, but seems to be a consistent feature during this decade.

\section{Discussion}

Based on the monthly averages over the upper $500 \mathrm{~m}$ at Station 4 Fyllas Bank, the seasonal cycles of temperature and salinity indicate minimum temperatures during April and minimum salinities during August, whereas the warmest conditions are encountered during November, and highest salinities during March. A closer view at the seasonal $\theta$,S-conditions from surface to bottom within this $500 \mathrm{~m}$ layer, however, reveals a completely different picture. Accordingly, the $0-75 \mathrm{~m}$ layer, which is primarily influenced by the Polar Water and the "Storis", indicates maximum warming during August-September. This is due to the seasonal cycle of atmospheric heat fluxes which is maximum during July-August off West Greenland (Stein, 1999). Also, this is a time when the near surface coastal waters extent farther offshore. Below $100 \mathrm{~m}$ depth, the deeper layers indicate maximum warming during October-November. These layers are predominantly influenced by the Irminger Water mass, which attains its seasonal signals upstream in the Irminger Sea. Maximum heat fluxes off East Greenland occur during July-August (Stein, 1999), and through advection of the Irminger Current component of the West Greenland Current this warming signal is carried to Fyllas Bank where it is observed during October-November.

The separation of the 0-75 m layer from the layers below $100 \mathrm{~m}$ was done to avoid contamination from the upper parts of the underlying Irminger Sea water (Schmidt and Send, 2007). As can be seen from Fig. 2b, the shape of the seasonal $\theta, \mathrm{S}$-curves below $100 \mathrm{~m}$ depth, indicate similarity in timing of minimum and maximum values. The timing of the salinity minimum, as displayed by the month (Fig. 2b), reveals a progression from deeper layers (May, June, July) to August-September in the $0-75 \mathrm{~m}$ top layer.

The time of the salinity minimum in the upper $75 \mathrm{~m}$ during August-September, matches well with that 
given by Schmidt and Send (2007), who observed the maximum freshwater peak at Fyllas Bank between July and September. Even if the seasonal curve for the upper layer is calculated using data to $100 \mathrm{~m}$, the results do not change substantially. These freshwater events which also emerge from the July CTD time series (1989-2006), lead to stable stratification at the sea surface as can be seen from the mid-1990s onwards (lower panel of Fig. 4). Salinities and temperatures indicate diluted $(\mathrm{S}<33.0)$, warm $\left(>3^{\circ} \mathrm{C}\right)$ surface waters at Station 4 Fyllas Bank. Prior to the arrival of the "Storis", salinities of the 0-75 $\mathrm{m}$ layer are $>33.5$, and are thus in the domain of the Polar Water. During June-July, salinity starts to drop to lower values.

Both the bottle data (1946-1988), and the more recent CTD data seem to reveal that the residual of the melt "Storis" leads to considerable reduced surface salinities during August-September, the "slack-period". Located on the offshore bank slope in about $900 \mathrm{~m}$ of water, the thermal properties of Station 4 of the Fyllas Bank Section below $150 \mathrm{~m}$ are mostly governed by the warm component of the West Greenland Current (Stein, 2005). This warm water lies below an upper layer of colder shelf water that extends offshore. In some years, this surface layer of shelf water extends far westward bringing much colder-than-normal water to Station 4 . The offshore extent may be controlled by the regional wind field. As indicated by Stein (2004), the subsurface (depths $>75 \mathrm{~m}$ ) thermohaline conditions at Station 4 are representative of West Greenland subsurface ocean variability. The salinity data analysis seems to corroborate the findings of Meyer (1953) that during mid-July to mid-August surface waters off West Greenland are most diluted, caused by the melting "Storis". Although surface temperatures attain their seasonal maximum during this time $\left(2.3^{\circ} \mathrm{C}\right.$ during August and September), they are $<2^{\circ} \mathrm{C}$ during the first seven months of the year. These temperatures, which Meyer (1953) hypothesized were responsible for dispelling cod from the shallows of the West Greenland fishing banks, are a consequence of both the Polar Water and the "Storis" melt. Whether, there are irregular distributions of cod off West Greenland during the "slack-period" as described by Meyer (1953), cannot be answered here.

Off Fyllas Bank, July hydrographic observations during the late-1940s to the late 1980 s clearly reveal the warm 1950s and 1960s, and the cold 1970s and 1980s. The late-1980s and the first part of the 2000s experienced Polar Water masses off Fyllas Bank during May-July, and from 1996 onwards, the available data show no Polar Water with temperatures $<1^{\circ} \mathrm{C}$. Thermohaline conditions during "Storis" years in the early-1990s to early-2000s reveal the existence of Polar Water west off Fyllas Bank during July, whereas during the ice free years there was little to no Polar Water observed.

This was consistent with the 2003 July observations under ice free conditions, which indicated much reduced vertical and horizontal extension of Polar Water, farther south off Frederikshaab Bank (Fig. 6). On top of the Bank, there is evidence of surface warming and very warm $\left(>6^{\circ} \mathrm{C}\right)$ surface water was observed in the offshore region of the Frederikshaab Section.

Sea surface temperature anomalies at Station 4 Fyllas Bank during July indicate a strong warming trend from the coldest conditions in 1989 to close to the warmest off West Greenland in 2008. This was followed by cooling to average conditions with both warm and cold anomalies of moderate amplitude. After the minimum temperature in 1989, warm anomalies were re-established in 1996 and strengthened through to 1998. From 2002 onwards, satellite imagery has revealed a new structure in the distribution of SST anomalies consisting of a band of colder-than-normal waters off East and West Greenland. Since this feature is present throughout the year and not just in July, it appears to be a new permanent feature of the circulation. It is assumed that the continuous warming has led to massive sea ice melt off East Greenland, and the ice drifts with the East Greenland Current along the shelves off East and West Greenland, strongly influencing the temperature and salinity of the near surface waters. The cooling signal is believed to be transported by the current system to West Greenland where it has a lasting effect on the SSTs off West Greenland. It would appear that there is inconsistency between July temperatures at Station 4 Fyllas Bank (warming trend) and satellite imagery (cooling trend). The difference in trends can be explained by the offshore location Station 4 on the western slope off Fyllas Bank. The SSTA pixel which represents thermal conditions at this site, is comprised by $64^{\circ} \mathrm{N}-63^{\circ} \mathrm{N}, 54^{\circ} \mathrm{W}-53^{\circ} \mathrm{W}$. Taking the July 2008 conditions into account, it is evident that the colder-thannormal conditions are restricted to the near coastal shelf regions, located about $220 \mathrm{~km}$ to the east of Station 4. This is further evidence for thermal changes taking place in the Polar Water domain.

\section{Acknowledgement}

The author appreciates the valuable comments of Dr. Ken Drinkwater, MRI Bergen, Norway, which added to the quality of this paper. 


\section{References}

BUCH, E. 2000. A monograph on the physical oceanography of the Greenland waters. Danish Meteorological Institute Scientific Report, 00-12, 405 p.

BUCH, E., S. A. PEDERSEN, and M. H. RIBERGAARD. 2004. Ecosystem Variability in West Greenland Waters J. Northw. Atl. Fish. Sci., 34: 13-28. doi:10.2960/J.v34. $\mathrm{m} 479$

CLARKE, R. A. 1984. Transport through the Cape FarewellFlemish Cap section. ICES Rapp. Proc.-Verb., 185: 120-130.

IGOSS, 2009. IGOSS nmc Reyn_SmithOlv2 monthly sea surface temperature anomoly database. http://iridl.ldeo. columbia.edu/SOURCES/.IGOSS/.nmc/.Reyn_SmithOIv2/.monthly/.ssta/figviewer.html?map.X.plotfirs $\mathrm{t}=30.5 \&$ map.X.plotlast $=389.5 \&$ map. $u r l=X+Y+$ fig+ colors + land + -fig\&map.T.value $=591.5$

NIC, 2009. Southwest Greenland Sea, National Ice Center. http://www.natice.noaa.gov/pub/East_Arctic/Greenland Sea/Greenland_Sea_southwest/

MEYER, A. 1953. Die erste deutsche Grönlandfischerei 1952/53. Hansa, 90: 1669-1671.

SCHLITZER, R. 2008. Ocean Data View, Version 3.4.2, 2008. http://odv.awi.de, accessed 28 February 2009.

SCHMIDT, S., and U. SEND. 2007. Origin and composition of seasonal Labrador Sea freshwater. J. Phys. Oceanogr., 37: 1445-1454. doi:10.1175/JPO3065.1
STEIN, MS 1988. Revision of list of NAFO standard oceanographic sections and stations. NAFO SCR Doc., No. 1, Serial No. N1432, 9 p.

1995a. Climatic conditions around Greenland - 1992. NAFO Sci. Coun. Studies, 22: 33-41. http://archive.nafo. int/open/studies/s22/stein.pdf

1995b. Climatic conditions around Greenland - 1993. NAFO Sci. Coun. Studies, 22: 43-49. http://archive.nafo. int/open/studies/s22/stein2.pdf

1999. Climatic conditions around Greenland - 1997. NAFO Sci. Coun. Studies, 32: 69-74. http://www.nafo.int/ publications/studies/no32/stein.pdf

2004. Climatic overview of NAFO Subarea 1, 19912000. J. Northw. Atl. Fish. Sci., 34: 29-40. doi:10.2960/J. v34.m474

2005. North Atlantic subpolar gyre warming-impacts on Greenland offshore waters. J. Northw. Atl. Fish. Sci., 36: 43-54. doi: 10.2960/J.v36.m568

2007. Warming periods off Greenland during 18002005: their potential influence on the abundance of cod (Gadus morhua) and haddock (Melanogrammus aeglefinus) in Greenlandic waters. J. Northw. Atl. Fish. Sci., 39:1-20. doi:10.2960/J.v39.m580

MS 2008. Climatic conditions around Greenland 2007. NAFO SCR Doc., No. 5, Serial No. N5490, 22 p. http://archive.nafo.int/open/sc/2008/scr08-005.pdf

WOD, 2005. World Ocean Database 2005 (WOD05). http:// www.nodc.noaa.gov/OC5/WOD05/pr_wod05.html, last accessed 28 February 2009. 